\title{
RECOGNIZING HOARDS IN COLLECTIONS. A POSSIBLE III CENTURY HOARD FROM THE STROLIN COLLECTION IN SCHIO (VI)
}

\begin{abstract}
This article presents a group of 31 Roman bronze coins (almost exclusively sestertii), which are part of a collection donated to the municipality of Schio (VI - Italy) in 2014. These specimens, illustrated here for the first time fully and properly identified, are recognized as a possible hoard of III century bronze coins, or at least a part of it, probably found locally. In fact, considering its characteristics of composition and chronology, it perfectly fits with the hoarding patterns of northern Italy. In addition to discussing the cohesion of this group as an ancient hoard, this article briefly presents the phenomenon of the hoarding of bronze coins in Italy during the third century, already extensively studied in literature, of which this group of coins constitutes a further addition to the already known examples.
\end{abstract}

Keywords: Hoarding patterns, III century AD, northern Italy, collections.

\section{INTRODUCTION}

Coin finds, and especially coin hoards, found in a specific archaeological context, are often useful to recognize and discover possible hoarding patterns; these are necessary to provide further and valuable information on various aspects of the ancient world, not only linked to the monetary economy and trade relations, but also to deduce indications on social structures, on the topography, and finally on historical vicissitudes occurred in a specific territory. However, sometimes the opposite could also happen: after recognizing into public or private collections groups of coins with similar characteristics that could be traced back to a unitary hoard ${ }^{1}$, and knowing local hoarding patterns, it is

\footnotetext{
${ }^{1}$ Activity which is not so rare in the study of numismatic collections; see, for example, AMANDRY 1993 or BERNARDELLI 2001.
}

\section{Alessandro Cattaneo}

University of Padova

alessandro.cattaneo@phd.unipd.it

DOI: 10.14795/j.v7i1_SI.479

ISSN $2360-266 \mathrm{X}$

ISSN-L 2360 - 266X 
possible to try to reconnect them to a specific territory, even if there are just few (or even no) notes about their finding.

In this article I will present one of these cases: a group of third century roman bronze coins (sestertii and asses) of the Strolin Collection (Schio, VI - Italy) ${ }^{2}$, could be easily reconnected with the territory, as it fits perfectly with the accumulation practices of northern Italy.

This, in addition to confirming the local origin of at least part of the collection, also adds new data to a hoarding pattern which is already quite well known.

\section{THE COLLECTION}

At the end of 2014 the municipality of Schio (VI) has inherited the interesting coin collection assembled during the first half of the XX century by Teopisto Strolin (18681951), a well-known numismatic enthusiast of the town. His collection, about 3500 pieces, ranges from antiquity to the modern age, but it is clear that the collector focused mainly on Roman republican, Roman imperial and Byzantine coins; equally interesting, even if less numerous, are some modern sections such as coins made by Italian mints and especially the Papal series, which are evidenced in his collection by both coins and medals ${ }^{3}$.

Teopisto Strolin was an atypical collector: even though he started from quite humble family conditions and, consequently, he could hardly have continued his studies beyond primary school ${ }^{4}$, during his life he managed to

\footnotetext{
2 The Strolin collection, property of the municipality of Schio (Vicenza), was reorganized and studied in 2015/2016 thanks to the convention signed between the municipality itself and the University of Padua Department of Cultural Heritage, whose referents, Lidia Zocche, Liana Ferretti, Michele Asolati and Andrea Ghiotto, deserve my most heartfelt thanks.

3 For more information about Teopisto Strolin and his collection, see CATTANEO 2016 and CATTANEO 2017.

4 Like his father before him, he worked as keeper of the city slaughterhouse. Strolin, therefore, belonged neither to a rich noble family nor to the new wealthy bourgeois class that in Italy between the 19th and 20th centuries began to devote itself to numismatics with increasing interest (on the coin collecting in Italy during these centuries, see GORINI 2007 and GORINI 2010).
}

put together a very noteworthy numismatic collection. In fact, despite the not always excellent quality of the pieces, the added value of his collection is also given by the way in which the coins were acquired: in an article on a local newspaper dated 1935 and dedicated to Strolin and to his collection ${ }^{5}$, it is said that he increased the number of coins in his possession not only through some purchases made on the antiquarian market, or through fees that were given to him in exchange for his numismatic advices, or even with gifts from relatives and friends, but also, and this is what interests us most, because he collected coins from finds he made on the territory, or that were donated to him by local discoverers to whom his numismatic passion was well known.

Unfortunately, due to the absence of any written documentation, data about the precise origin of almost all these coins in the collection have been lost. However, it is possible to make some hypotheses, starting from the grade of conservation and from the comparison with the monetary circulation documented locally thanks to numerous publications on the subject. In the area of Schio ${ }^{6}$, in fact, there are plentiful and widespread archaeological finds ${ }^{7}$ and these, for Strolin, had to represent one of the major attractions since they allowed him to obtain new specimens without any expense. These possible findings, which are today part of the collection, are not limited to a short chronological period, but they extend continuously from the Greek age to the contemporary one ${ }^{8}$; these characteristics

\section{TAGLIAFERRO 1935.}

6 The territory of Schio was interested by anthropic frequentations since prehistoric times thanks to its favourable position on the slopes of Mount Summano and at the entrance to the Val d'Astico. For further information, see FURLANETTO, RIGONI 1987 and GAMBA 2012 (with previous bibliography).

7 Specifically for coin finds see, for example, RMRVe, $\mathrm{IV} / 2,26$.

8 Among the specimens donated to the municipality of Schio, we could assume as coins of local origin a group of six drachms of Massaliotan imitation, as well as the other pre-Roman coins in the collection. Moving to the Late Antiquity and to the Byzantine period, the specimens that would fit perfectly into a pattern of local discoveries, are an as of Vespasian with the 
therefore make them an important historicalarchaeological evidence to the monetary economy of the area in ancient and modern times.

\section{THE HOARD OF ROMAN SESTERTII AND ASSES AND THE HOARDING OF BRONZE COINAGE IN NORTHERN ITALY DURING THE III CENTURY AD}

Among the probable local findings, both for the characteristics of the specimens that will be described below, and for the comparison with the hoarding pattern of the territory, it was possible to recognize in the Strolin collection also a group of roman coins dating back to the third century AD.

These specimens, ranging from the reign of Severus Alexander (222-235 $\mathrm{AD}$ ) to Philip I (244-249 AD), are characterized by a homogeneous patina, brown in colour with more or less uniform corrosion of intense green, and generally by good conservation conditions (Fig. 1); these characteristics allow us to assume that the coins were undoubtedly part of a unitary hoard, e.g. a small treasure, probably buried around the middle of the third century $\mathrm{AD}^{9}$.

Unfortunately, within the collection, these specimens had not been preserved all together so that their common origin could be maintained ${ }^{10}$, but a careful autoptic analysis of

countermark XLII (in particular, about this coin, see ASOLATI 2018) and the group of follis and decanumma of the military mint of Salona in Dalmatia. Finally, coming to more recent periods, we could mention here, for example, soldi and anonymous bagattini of Venice or also the large group of Habsburg money of Gorizia. For more information and for the reasons that led to assigning these issues to the territory, see CATTANEO 2017, 23-29, with previous bibliography.

9 The repetitiveness of monetary types for some authorities may also contribute to the recognition of this group of coins as a unitary nucleus (see, for example, Catalogue nos. 1-2; 3-4; 12-13; 16-17).

10 Strolin, in fact, has tried to order his collection, and in particular the Roman imperial series, by authority; moreover, it should be considered also the changes and displacements, even random, that have affected his collection after his death in 1951, when it was put aside in a basement room by the heirs for more than 60 years, before the work of reorganization made after the all the pieces has allowed us to assign to the possible hoard 31 coins $^{11}$, all with the same characteristics of conservation mentioned above. It is not known whether these represent the entire initial composition of the hoard, also considering an inevitable subjectivity in the identification of these specimens, as well as the possibility that some coins may have been sold or used by the collector for exchanges ${ }^{12}$.

Despite this, however, it is possible

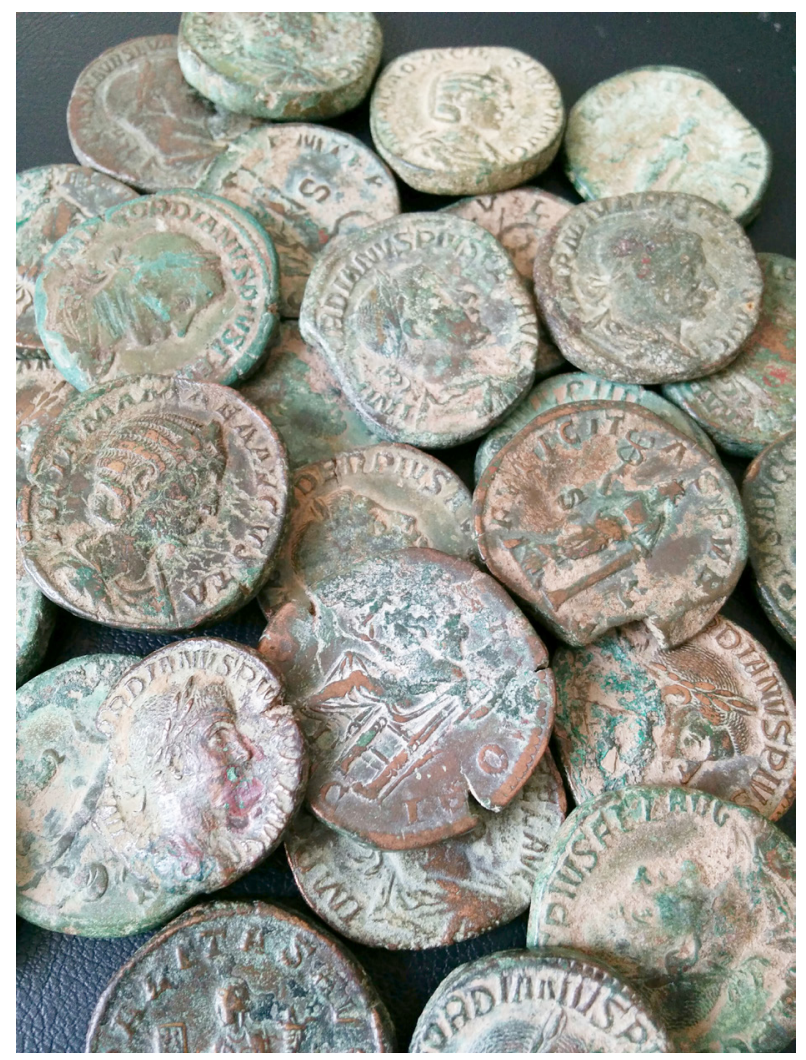

Fig. 1. The group of roman coins of the Strolin Collection

to make some considerations regarding the denominations and the authorities and compare them with the northern Italian hoarding pattern, to conclude by stating a certain local origin of the hoard.

donation to the municipality in 2014.

11 See the Catalogue in the next paragraph.

12 As it has been said before, the coins donated to the municipality of Schio are about 3500; but when Strolin was alive his entire collection was much more numerous, so that in the already mentioned article on the local newspaper (TAGLIAFERRO 1935), it is claimed to be of over 12000 specimens; so, it seems probable that part of the collection has been sold by Strolin himself or, later, by his heirs. 
Our group of coins, as already mentioned before, covers a chronological arc from Severus Alexander to Philip I: in particular there are 13 sestertii of Severus Alexander (222-235 $\mathrm{AD})$, two of which are in the name of Julia Mamaea; 11 coins minted under the authority of Gordian III (238-244 AD); and it ends with 5 specimens of Philip I (244-249 AD), one dedicated to his wife Otacilia Severa. As it can be seen, the only authority of the period that doesn't appear is Maximinus ${ }^{13}$, for whom there are several coins in the Strolin collection, but none of them with characteristics of patina, wear and corrosion that could bring it closer to those of this group.

All the coins of the possible hoard were minted in Rome, and considering the denomination, they are exclusively sestertii, with the sole exception of two asses, issued by Gordian III and Philip I (Cat. nos. 19 and 27).

These characteristics of composition and chronology perfectly fit with the hoarding patterns of northern Italy and, in particular, of the Regio $X$ Venetia et Histria. In fact, the phenomenon of the withdrawal of bronze coins characterizes great part of the III century $\mathrm{AD}$, and can be easily followed through the archaeological traces constituted by hoards. This phenomenon, that could not be attributed to exclusively local political and economic reasons ${ }^{14}$, affects vast areas of the empire ${ }^{15}$, and it has its common denominator in the selection of the sestertii, which are by far the most treasured denomination, while some

\footnotetext{
13 Obviously if we don't consider Gordian I and II, Pupienus and Balbinus, whose coin production was limited and whose specimens are therefore much rarer and harder to find in most of the contemporary hoards (see, for example, the hoard of Gambugliano: RMRVe, IV/1, 18/1).

14 GORINI 2002, 184-185. Regarding the monetary situation of the Roman Empire during the III century $\mathrm{AD}$, the bibliography is vast; we could mention here just some works, such as CALLU 1969, CALLU 1975, CRAWFORD 1975, CORBIER 2005, LO CASCIO 2005.

15 The geographical distribution of the hoards indicates that, according to the data that we have so far, the areas most affected are particularly located in northern Italy and Sardinia, while central and southern Italy are only marginally or not at all affected (BERNARDELLI 2006a, 71).
}

differences in the chronological composition of the hoards could be seen among different regions. For northern Italy, as has already been amply discussed in literature ${ }^{16}$, the available data clearly indicate that most of the coins belong to the end of II/beginning of the III century $\mathrm{AD}$, while in Sardinia and central Italy issues of the III century, and in particular of the second half of the century, tend to prevail clearly over the previous ones. Moreover, in northern Italy later hoards close before the reign of Gallienus, whose issues almost never appear, and most of them have latest coins that could be placed around the middle of the III century $\mathrm{AD}^{17}$.

Factors that are generally indicated at the base of the withdrawal of the circulation of bronze coins (and particularly of sestertii) and of the consequent formation of hoards are essentially two: the decided contraction of the bronze issues that seems to be registered from the end of the II century AD and at the beginning of the III century $\mathrm{AD}$, and that will culminate with the end of the production around $260 \mathrm{AD}^{18}$; and, above all, the marked fall of the intrinsic value of silver coinage, taking into account also the possibility of a forced maintenance of the exchange with the divisional bronze coinage inherited from the Augustan system.

Moreover, differences among the areas seem to indicate that in northern Italy the supply and exchange of bronze coins should be more difficult (which is why there is a greater presence of coins of the II/early III century): therefore in this area these facts, added to the contraction of bronze issues, have played an important role in the formation of hoards ${ }^{19}$.

\footnotetext{
16 On this argument, see in particular the already cited BERNARDELLI 2006a and also BERNARDELLI 2014 with previous bibliography.

17 In other regions, however, such as the already mentioned Sardinia and central Italy, there is a strong concentration of hoards that close later with issues of Gallienus and, in some cases, even later.

18 GORINI 1987, 262-263; GORINI 1993, 98-99.

19 In addition to this, we should consider also the phenomenon of imitation and production through fusion of sestertii and asses, that in this region appears frequently in hoards of the late II/early III century AD;
} 


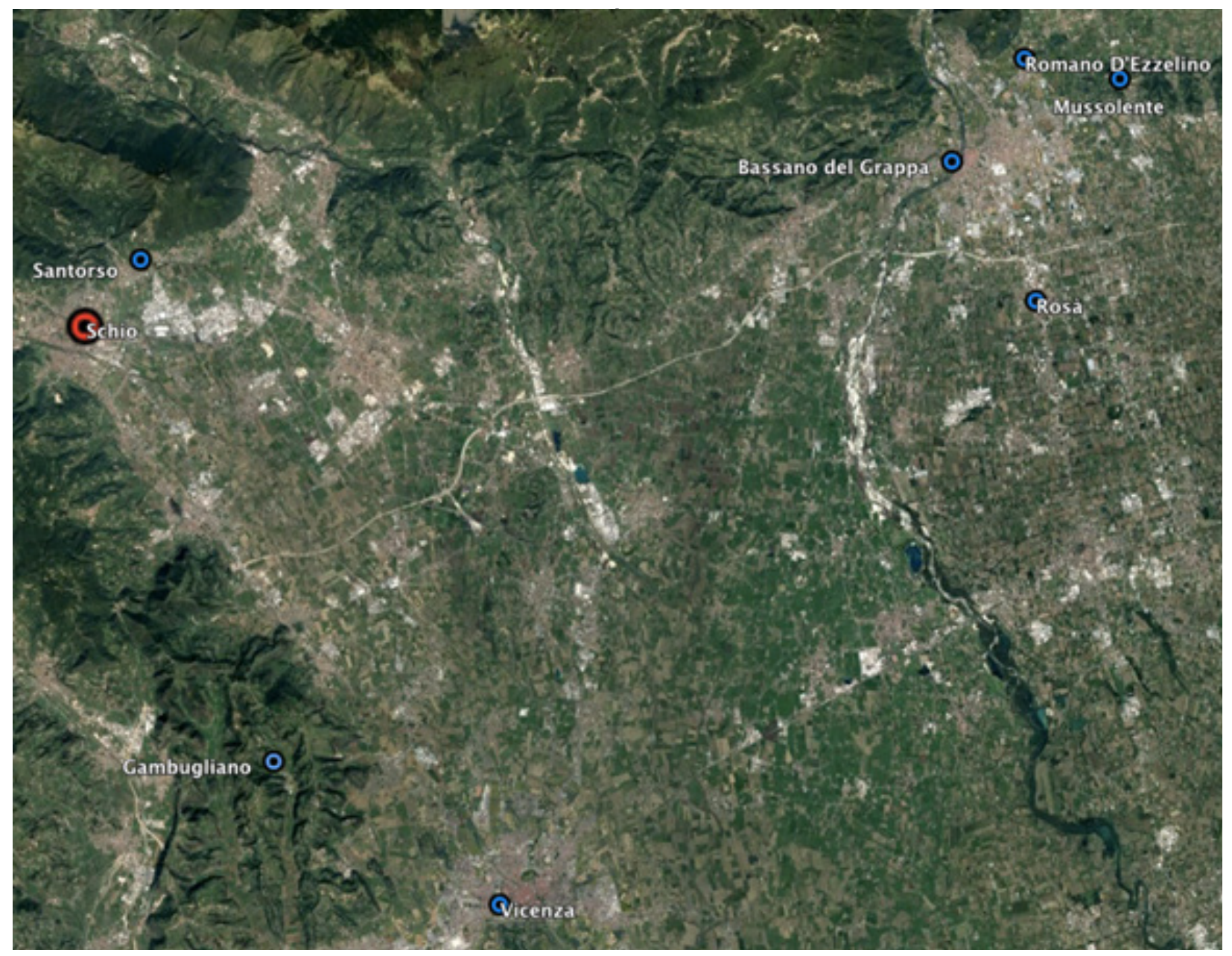

Fig. 2. The northern part of the province of Vicenza, with the indication of the II/III century hoards known nowadays

In fact, looking at the chronological trend of hoards in the area, it is clear that the phenomenon of hoarding has developed here with a certain homogeneity since the first half of the III century, and then it concentrates in the years around the middle of the century with a few cases that end just beyond ${ }^{20}$.

The selection of bronze, in the light of

this phenomenon, rather than the work of forgers, seems to be an answer to the need to supply a monetary circuit that required more divisional bronze currency (KING 1996, 243-245; ALFÖLDI 2004; ARSLAN 2004; BERNARDELLI 2014, 112).

20 However, based on the wear and, more generally, on the state of conservation of coins of the end of the II/beginning of the III century $\mathrm{AD}$ which were found in the hoards, we could not exclude, as already stated by Buttrey in the study of the hoard from Bordeaux (BUTTREY 1972 and BUTTREY 1981) and by Gorini for the hoard from Camin (GORINI 1993, 100), that all the hoards were actually buried around 260/270 AD. Contra, CRISAFULLI 2008, 124-126. the devaluation of silver, is due to the socalled Gresham's law, a monetary principle stating that "bad money drives out good one". Moreover, as regards the denominations, on the other hand, the scarce presence of asses in hoards is probably attributable to the limited interest in their hoarding, a phenomenon that generally always prefers the highest range of value. In this sense, the precise choice of the public towards the sestertii is due to the fact that they were selected because they were perceived as stable and reliable, in particular for their historic fiduciary dimension and their adequate purchasing power, compared to the antoninianus, which by the middle of the III century AD had been reduced to a $95 \%$ copper $\operatorname{coin}^{21}$.

The probable hoard recognized into the Strolin Collection, consequently, as we

${ }^{21}$ CALLU 1969, 119; BERNARDELLI 2014, 128-136. 
have already stated, fits perfectly with these hoarding patterns and allow us to say with reasonable certainty that it was found in the proximity of the city of Schio. In addition, it would suit perfectly into an area, that of the northern part of the province of Vicenza, which was already the site of other monetary hoards during the II and III centuries. Looking at the data known until now, in fact, we could mention today other 7 hoards, most of which are already well studied in literature (Fig. 2):

- Bassano del Grappa: 112 bronze coins (111 sestertii + 1 as) from Trajan to Septimius Severus ${ }^{22}$;

- Gambugliano: 16 sestertii from Hadrian to Gordian III (AD 240) minted in Rome and a further one from the mint in Viminacium (Trajan Decius, AD 251) ${ }^{23}$;

- Mussolente: 118 sestertii from Domitian to Commodus ${ }^{24}$;

- Romano d'Ezzelino: unknown number of bronze coins ending with Philip $\mathrm{I}^{25}$;

- Rosà: 10 sestertii from Marcus Aurelius to Philip I ${ }^{26}$;

- Santorso: various groups of coins, where the most recent date back to $249 \mathrm{AD}$, still under study ${ }^{27}$;

- Vicenza: unspecified number of bronze coins, now dispersed ${ }^{28}$.

The documentation, then, becomes even richer if we extend our gaze slightly to the other provinces of the Veneto region, that constituted a large part of the territory of the RegioX Venetia et Histria, with some significant hoards of the III century as well. Most of these have already been widely cited and analysed in previous summary studies ${ }^{29}$ and they already constitute a rich and varied source of

\footnotetext{
22 SORDA 1981; RMRVe, IV/2, 2/16(1).

${ }^{23} R M R V e, \mathrm{IV} / 1,18 / 1$.

24 SACCOCCI 1988; RMRVe, IV/2, 17/6.

25 ARSLAN 1995, 9.

26 PAVONI 2004.

27 A first publication, without the list of coins, in BERNARDELLI 2006b.

${ }_{28} R M R V e$, IV/1, 42/29; ARSLAN 1997, 275.

29 See, for example, BERNARDELLI 2006a and BERNARDELLI 2014.
}

information: Martellago $(\mathrm{VE})^{30}$, Ca'Noghera $(\mathrm{VE})^{31}$, Camponogara (VE) ${ }^{32}$, Quarto d'Altino $(\mathrm{VE})^{33}$, Camin $(\mathrm{PD})^{34}$, Asolo $(\mathrm{TV})^{35}$, Faé $(\mathrm{TV})^{36}$, Monastier (TV) ${ }^{37}$, Sgarbariol/Oderzo $(\mathrm{TV})^{38}$, S. Polo di Piave (TV) ${ }^{39}$, Curago $(\mathrm{BL})^{40}$. However, new data on previously unknown hoards continue to be added to these, such as the case of the one from San Rocco a Ceneda/ Vittorio Veneto (TV) ${ }^{41}$.

The high number of this type of hoards in the regional territory, if on the one hand it appears to be the main consequence of the monetary crisis described above, it is also an effect of the politically unstable climate of the period, due to the numerous military operations that saw particularly involved the Regio X Venetia et Histria ${ }^{42}$.

\section{CONCLUSIONS}

The hoarding of bronze money during the III century AD, and more specifically in the decades immediately after the middle of the century, occurred in a period of political, military, economic, but also financial and monetary crisis of the Roman Empire. It is a phenomenon today quite well known. It is in this century that we see the change in the monetary system introduced by Augustus: the denarius disappeared, replaced by the antoninianus, whose silver content decreases more and more with the passing of the years; from $260 \mathrm{AD}$, moreover, also asses, dupondii and sestertii, that from the end of the II century AD recorded various contractions in their production, were not issued anymore.

These conditions have contributed

\footnotetext{
${ }^{30} \mathrm{RMRVe}, \mathrm{VI} / 3,8 / 2$.

${ }^{31} R M R V e, \mathrm{VI} / 2,9 / 9$.

${ }^{32} R M R V e, \mathrm{VI} / 3,3 / 1$.

33 RMRVe, VI/1, 53(F2).

${ }^{34}$ GORINI 1993.

$35 R M R V e, \mathrm{II} / 1,2 / 26(2)$.

${ }^{36} \mathrm{RMRVe}, \mathrm{II} / 1,8 / 40$.

37 RMRVe, II/1, 27/4(1).

$38 R M R V e, \mathrm{II} / 2,8 / 15$.

39 RMRVe, II/2, 13/1(1).

${ }^{40} R M R V e, \mathrm{I} / 1,12(2)$.

${ }_{41}$ CRISAFULLI 2014

42 GORINI 1976, 49-50; CRISAFULLI 2008, 119-127

(with previous bibliography).
} 
to determine in the III century a particular phenomenon: the selective hoarding of sestertii, which were probably perceived as "good currency" compared to the new and increasingly devalued issues, and then quickly withdrawn from the monetary circuit.

This phenomenon, widespread in large areas of the Roman Empire, is witnessed by numerous treasures almost exclusively made up of sestertii and it also involves widely Veneto region, where different hoards of this period are today well known.

For all these reasons even the group of coins of the Strolin collection, that for its characteristics of wear, patina and oxidation we have brought back to a unitary hoard, belongs with certainty to this phenomenon.

\section{CATALOGUE}

1. Severus Alexander, Sestertius, Rome, AD 225

D/ IM[P C]AES [M AVR] SE[V AL]EXANDER AVG Bust of Severus Alexander, laureate, draped, cuirassed, right

R/ POINTIF MAX [TR P] IIII COS P [P]

Severus Alexander, in military dress, standing left, holding globe in right hand and inverted spear in left hand; in field, S-C

Æ; 29,5 mm; 22,17 g; $12 \mathrm{~h}$

RIC, IV/2, p. 106, n. 439d

(Inv.n. ST0623)

2. Severus Alexander, Sestertius, Rome, AD 225

D/ [IM]P CAES M AVR SEV ALEXANDER AVG

Bust of Severus Alexander, laureate, draped, cuirassed, right

R/ POINTIF MAX TR P IIII COS [P P]

Severus Alexander, in military dress, standing left, holding globe in right hand and inverted spear in left hand; in field, S-C

Æ; $31 \mathrm{~mm} ; 20,58 \mathrm{~g} ; 12 \mathrm{~h}$

RIC, IV/2, p. 106, n. 439d

(Inv. n. ST0624)

3. Severus Alexander, Sestertius, Rome, AD 230

D/ IMP SEV ALE-[XANDER A]VG

Bust of Severus Alexander, laureate, draped over left shoulder, right

R/ P M TR P VII-II - COS III P P

Sol, radiate, head left, standing front, raising right hand and holding whip in left hand; in field, S-C

Æ; $32 \mathrm{~mm} ; 20,74 \mathrm{~g} ; 12 \mathrm{~h}$

RIC, IV/2, p. 110, n. 500

(Inv.n. ST0628)

4. Severus Alexander, Sestertius, Rome, AD 230

D/ [I]MP SEV ALE-XANDER AVG

Bust of Severus Alexander, laureate, draped over left shoulder, right
R/ P M TR P V-[IIII] COS III P P

Sol, radiate, head left, standing front, raising right hand and holding whip in left hand; in field, S-C

Æ; $29 \mathrm{~mm} ; 15,07 \mathrm{~g} ; 6 \mathrm{~h}$

RIC, IV/2, p. 110, n. 500

(Inv. n. ST0629)

5. Severus Alexander, Sestertius, Rome, AD 233

D/ IMP ALEXAN-DER PIVS AVG

Bust of Severus Alexander, laureate, draped over left shoulder, right

R/ LIBERA[LITAS AVG]VSTI V

Liberalitas, draped, standing left, holding abacus in right hand and cornucopiae in left hand; in field, S-C

Æ; $29 \mathrm{~mm} ; 13,22 \mathrm{~g} ; 12 \mathrm{~h}$

RIC, IV/2, p. 112, n. 533

(Inv.n.ST0631)

6. Severus Alexander, Sestertius, Rome, AD 234

D/ IMP ALEXANDE[R PI]VS AVG

Bust of Severus Alexander, laureate, draped, cuirassed, right

R/ P M TR P XIII COS III P P

Sol, radiate, walking left, raising right hand and holding whip in left hand; in field, S-C

Æ; $30 \mathrm{~mm} ; 17,49 \mathrm{~g} ; 12 \mathrm{~h}$

RIC, IV/2, p. 113, n. 538d

(Inv. n. ST0633)

7. Severus Alexander, Sestertius, Rome, AD 222-231

D/ IMP CAES [M] AVR SEV ALEXANDER AVG

Bust of Severus Alexander, laureate, draped, right

R/ IOV[I V]LTORI

Jupiter, half draped, seated left, holding Victory in right hand and sceptre in left hand; in exergue, $\mathrm{SC}$

Æ; $32 \mathrm{~mm} ; 20,68 \mathrm{~g} ; 1 \mathrm{~h}$ 
RIC, IV/2, p. 115 , n. 560

(Inv. n. ST0638)

8. Severus Alexander, Sestertius, Rome, AD 231-235

D/ IMP ALEXANDER PIVS AVG

Bust of Severus Alexander, laureate, draped, cuirassed, right

R/ MARS VLTOR

Mars, helmeted, in military dress, walking right, holding shield in right hand and spear in left hand; in field, S-C

Æ; $30 \mathrm{~mm} ; 19,03 \mathrm{~g} ; 2 \mathrm{~h}$

RIC, IV/2, p. 120, n. 635d

(Inv. n. ST0646)

9. Severus Alexander, Sestertius, Rome, AD 231-235

D/ [IMP A]LEXANDER PIVS AVG

Bust of Severus Alexander, laureate, draped over left shoulder, right

R/ [PROVI]DENTIA AVG

Providentia, draped, standing front, head left, holding two corn-ears in right hand over modius and cornucopiae in left hand; in field, $\mathrm{S}-\mathrm{C}$

Æ; $32 \mathrm{~mm} ; 21,64 \mathrm{~g} ; 12 \mathrm{~h}$

RIC, IV/2, p. 121, n. 642b

(Inv.n. ST0648)

10. Severus Alexander, Sestertius, Rome, AD 231-235

D/ IMP ALEXANDER PIVS AVG

Bust of Severus Alexander, laureate, draped over left shoulder, right

R/ PROVIDENTIA AVG

Providentia, draped, standing front, head left, holding corn-ears in right hand over modius and anchor in left hand; in field, S-C

Æ; $30 \mathrm{~mm} ; 19,71 \mathrm{~g} ; 12 \mathrm{~h}$

RIC, IV/2, p. 121, n. 645b

(Inv. n. ST0655)

11. Severus Alexander, Sestertius, Rome, AD 231-235

D/ IMP ALEXANDER PIVS AVG

Bust of Severus Alexander, laureate, draped over left shoulder, right

R/ SPES PVBLICA

Spes, draped, walking left, holding flower in right hand and raising skirt with left hand; in field, S-C

Æ; $30 \mathrm{~mm} ; 14,18 \mathrm{~g} ; 12 \mathrm{~h}$

RIC, IV/2, p. 121, n. 648b

(Inv. n. ST0659)

12. Severus Alexander for Julia Mamaea, Sestertius, Rome, AD 222-235
D/ IVLIA MAMAEA AVGVSTA

Bust of Julia Mamaea, diademed, draped, right

R/ FELICITAS PVBLICA

Felicitas, draped, standing front, head left, legs crossed, holding caduceus in right hand and leaning on column with left arm; in field, S-C Æ; $30 \mathrm{~mm} ; 21,52 \mathrm{~g} ; 1 \mathrm{~h}$

RIC, IV/2, p. 125, n. 676

(Inv.n. ST0669)

13. Severus Alexander for Julia Mamaea, Sestertius, Rome, AD 222-235

D/ [I]VLIA MAMAEA AVGVSTA

Bust of Julia Mamaea, diademed, draped, right

R/ FELICIT-AS PVB[LICA]

Felicitas, draped, standing front, head left, legs crossed, holding caduceus in right hand and leaning on column with left arm; in field, S-C E; $30 \mathrm{~mm} ; 20,49 \mathrm{~g} ; 12 \mathrm{~h}$ RIC, IV/2, p. 125 , n. 676

(Inv. n. ST0671)

14. Gordian III, Sestertius, Rome, AD 238-239

D/ IMP CAES M ANT GORDIANVS AVG

Bust of Gordian III, laureate, draped, cuirassed, right

R/ VICTORIA AVG

Victory, winged, draped, advancing left, holding wreath in extended right hand and palm, sloped over left shoulder, in left hand; in field, $\mathrm{S}-\mathrm{C}$

Æ; $29 \mathrm{~mm} ; 19,41 \mathrm{~g} ; 12 \mathrm{~h}$

RIC, IV/3, p. 43, n. 258a

(Inv. n. ST0713)

15. Gordian III, Sestertius, Rome, AD 240

D/ IMP GORDIANVS PIVS FEL AVG

Bust of Gordian III, laureate, draped, cuirassed, right

R/ P M TR P III COS [P P]

Gordian III, laureate, togate, seated left on curule chair, holding globe in extended right hand and sceptre in left hand; in exergue, S-C Æ; 29,5 mm; 18,59 g; $1 \mathrm{~h}$

RIC, IV/3, p. 47, n. 294a

(Inv. n. ST0723)

16. Gordian III, Sestertius, Rome, AD 241-244

D/ IMP GORDIANVS PIVS FEL AVG

Bust of Gordian III, laureate, draped, cuirassed, right

R/ AETERNITATI AVG

Sol, nude except for cloak around shoulders, 
standing front, head left, raising right hand and holding globe in left hand; in field, S-C Æ; $30 \mathrm{~mm} ; 23,31 \mathrm{~g} ; 6 \mathrm{~h}$ RIC, IV/3, p. 48, n. 297a

(Inv. n. ST0725)

17. Gordian III, Sestertius, Rome, AD 241-244

D/ [IM]P GORDIANVS PIVS FEL AV[G] Bust of Gordian III, laureate, draped, cuirassed, right

R/ AETER[NI]TATI AVG

Sol, nude except for cloak around shoulders, standing front, head left, raising right hand and holding globe in left hand; in field, S-C Æ; 28 mm; 19,93 g; $6 \mathrm{~h}$ RIC, IV/3, p. 48, n. 297a

(Inv. n. ST0726)

18. Gordian III, Sestertius, Rome, AD 241-244

D/ IMP GORDIANVS PIVS FEL AVG

Bust of Gordian III, laureate, draped, cuirassed, right

R/ AETERNITAT[I A]VG

Sol, nude except for cloak around shoulders, standing right, head left, raising right hand and holding globe in left hand; in field, S-C Æ; $30 \mathrm{~mm} ; 17,67 \mathrm{~g} ; 12 \mathrm{~h}$ RIC, IV/3, p. 48, n. 297a

(Inv.n. ST0728)

19. Gordian III, Sestertius, Rome, AD 241-244

D/ IM[P G]ORDIANVS PIVS FEL AVG

Bust of Gordian III, laureate, draped, cuirassed, right

R/ IOVI STA[T]ORI

Jupiter, nude, standing front, head left, holding long sceptre in right hand and thunderbolt in left hand; in field, S-C

E; $32 \mathrm{~mm} ; 18,64 \mathrm{~g} ; 12 \mathrm{~h}$

RIC, IV/3, p. 48, n. 298a

(Inv. n. ST0731)

20. Gordian III, Sestertius, Rome, AD 241-244

D/ IMP GORD[IAN]VS PIVS FEL AVG

Bust of Gordian III, laureate, draped, cuirassed, right

R/ [LAET]ITIA AVG N S

Laetitia, draped, standing left, holding wreath in extended right hand and anchor set on ground in left hand; in field, S-C

Æ; $31 \mathrm{~mm} ; 15,86 \mathrm{~g} ; 12 \mathrm{~h}$

RIC, IV/3, p. 48, n. 300a

(Inv. n. ST0735)
21. Gordian III, As, Rome, AD 241-244

D/ IM[P G]ORDIANVS PIVS FEL AVG

Bust of Gordian III, laureate, draped, cuirassed, right

R/ VIRTVTI AVG[V]S[T]I

Hercules, nude, standing right, resting right hand on hip and resting left hand on club set on rock; beside club, lion-skin; in field, S-C Æ; $24 \mathrm{~mm} ; 7,92 \mathrm{~g} ; 12 \mathrm{~h}$

RIC, IV/3, p. 49, n. 309

(Inv. n. ST0765)

22. Gordian III, Sestertius, Rome, AD 244

D/ IMP GORDIA[NVS PIVS] FEL AVG

Bust of Gordian III, laureate, draped, cuirassed, right

R/ FOR[TV]NA REDVX

Fortuna, draped, seated left, holding rudder set on ground in right hand and cornucopiae in left hand; under seat, wheel; in exergue, $\mathrm{S}-\mathrm{C}$ Æ; $32 \mathrm{~mm}$;22,39 g; $12 \mathrm{~h}$ RIC, IV/3, p. 51, n. 331a

(Inv. n. ST0754)

23. Gordian III, Sestertius, Rome, AD 244

D/ IMP GORDIANVS PIVS FEL AVG

Bust of Gordian III, laureate, draped, cuirassed, right

R/ SECVRIT PERPET

Securitas, draped, standing left with legs cross, leaning left arm on column, and holding sceptre in right hand; in field, S-C

Æ; $31 \mathrm{~mm} ; 16,27 \mathrm{~g} ; 12 \mathrm{~h}$

RIC, IV/3, p. 51, n. 335a

(Inv. n. ST0757)

24. Gordian III, Sestertius, Rome, AD 244

D/ IMP GORDIANVS PIVS FEL AVG

Bust of Gordian III, laureate, draped, cuirassed, right

R/ P M TR P VII COS II P P

Mars, helmeted, in military dress, walking right, holding shield in right hand and spear in left hand; in field, $S-C$

Æ; 28,5 mm; 18,25 g; $12 \mathrm{~h}$

RIC, IV/3, p. 52, n. 339a

(Inv.n. ST0762)

25. Philip I, Sestertius, Rome, AD 247

D/ IMP M IVL PHILIPPVS [AVG]

Bust of Philip I, laureate, draped, cuirassed, right

R/ P M TR P IIII COS II P P

Felicitas, draped, standing left, holding long 
caduceus in right hand and cornucopiae in left hand; in field, S-C

Æ; $28 \mathrm{~mm} ; 17,13 \mathrm{~g} ; 12 \mathrm{~h}$

RIC, IV/3, p. 87, n. 150a

(Inv. n. ST0770)

26. Philip I, Sestertius, Rome, AD 244-249

D/ IMP M IVL PHILIPPVS AVG

Bust of Philip I, laureate, draped, cuirassed, right

R/ AEQVITAS AVGG

Aequitas, draped, standing left, holding scales in right hand and cornucopiae in left hand; in field, S-C

Æ; 29,5 mm; 18,49 g; $12 \mathrm{~h}$

RIC, IV/3, p. 89, n. 166a

(Inv. n. ST0776)

27. Philip I, As, Rome, AD 244-249

D/ IMP M IVL PHILIPPVS AVG

Bust of Philip I, laureate, draped, cuirassed, right

R/ AEQVITAS AVGG

Aequitas, draped, standing left, holding scales in right hand and cornucopiae in left hand; in field, $S-C$

Æ; $25 \mathrm{~mm} ; 9,07 \mathrm{~g} ; 6 \mathrm{~h}$

RIC, IV/3, p. 89, n. 166b

(Inv. n. ST0794)

28. Philip I, Sestertius, Rome, AD 244-249

D/ [I]MP M IVL PHILIPPVS AVG

Bust of Philip I, laureate, draped, cuirassed, right

R/ FELICITAS TEMP

Felicitas, draped, standing left, holding long caduceus in right hand and cornucopiae in left hand; in field, S-C

Æ; $29 \mathrm{~mm} ; 19,13 \mathrm{~g} ; 12 \mathrm{~h}$

RIC, IV/3, p. 90, n. 169a

(Inv. n. ST0779)

29. Philip I, Sestertius, Rome, AD 244-249

D/ IMP M IVL PHILIPPVS AVG

Bust of Philip I, laureate, draped, cuirassed, right

R/ LIBERALITAS AVGG II

Liberalitas, draped, standing left, holding abacus in right hand and cornucopiae in left hand; in field, S-C

Æ; $30 \mathrm{~mm} ; 22,21 \mathrm{~g} ; 12 \mathrm{~h}$

RIC, IV/3, p. 91, n. 180a

(Inv. n. ST0784)
30. Philip I, Sestertius, Rome, AD 244-249

D/ IMP [M IV]L PHI[LIPPV]S AV[G]

Bust of Philip I, laureate, draped, cuirassed, right

R/ VIC[T]OR[IA] AVG

Victoria, winged, draped, running right, holding wreath in right hand and palm in left hand; in field, $S-C$

Æ; $28 \mathrm{~mm} ; 16,93 \mathrm{~g} ; 12 \mathrm{~h}$

RIC, IV/3, p. 92, n. 191a

(Inv. n. ST0789)

31. Philip I for Marcia Otacilia Severa, Sestertius, Rome, AD 244-249

D/ MARCIA OTACIL SEVERA AVG

Bust of Otacilia Severa, diademed, draped, right

R/ CONCORDIA AVGG

Concordia, draped, seated left, holding patera in right hand and double cornucopiae in left hand; in exergue, $\mathrm{S}-\mathrm{C}$

Æ; $28 \mathrm{~mm} ; 19,05 \mathrm{~g} ; 1 \mathrm{~h}$

RIC, IV/3, p. 94, n. 203

(Inv. n. ST0800) 


\section{BIBLIOGRAPHY}

ALFÖLDI 2004

Alföldi, R.M., Le monete fuse nel II e III secolo nell'Impero romano e le loro matrici di terracotta: la discussione attuale. In: Vanni, F.M./Bussi, S. (eds.), La moneta fusa nel mondo antico. Quale alternativa alla coniazione? Convegno internazionale di studio (Arezzo, 19-20 settembre 2003) (Milano: s.n.), 227-233

\section{AMANDRY 1993}

Amandry, M., Un petit trésor trouvé en Italie du Sud au Musée Savoisien, Bulletin de la Société Française du Numismatique 48, 575-578

ARSLAN 1995

Arslan, E., Il Ripostiglio di Biassono (Milano) 1975 (Milano: Edizioni ennerre)

\section{ARSLAN 1997}

Arslan, E., Albino 1961: uno o due ripostigli monetali di III-IV secolo?, Notizie archeologiche bergomensi 5/1997, 273-307

\section{ARSLAN 2004}

Arslan, E., La moneta falsa fusa in Italia in età imperiale: prospettive per la ricerca. In: Vanni, F.M./Bussi, S. (eds.), La moneta fusa nel mondo antico. Quale alternativa alla coniazione? Convegno internazionale di studio (Arezzo, 19-20 settembre 2003) (Milano: s.n.), 195-226

\section{ASOLATI 2018}

Asolati, M., Nuove scoperte sulle monete bronzee d'età imperiale con contromarche XLII e LXXXIII. In: Vigoni, A. (ed.), Percorsi nel passato. Miscellanea di studi per $i 35$ anni del Gr.A.V.O. e i 25 anni della Fondazione Colluto (Rubano: Grafiche Turato Edizioni), 253-265

\section{BERNARDELLI 2001}

Bernardelli, A., Un probabile ripostiglio di monete greche al Museo Civico di Vicenza (sec. III-II a.C.). In: Saccocci, A. (ed.), Inspecto Nummo. Scritti di numismatica, medaglistica e sfragistica offerti dagli allievi a Giovanni Gorini (Padova: Esedra editrice), 3-22

\section{BERNARDELLI 2006a}

Bernardelli, A., La tesaurizzazione di moneta di bronzo in Italia nel III secolo d.C. e la legge di Gresham: alcune considerazioni. In: Asolati, M./Gorini, G. (eds.), I ritrovamenti monetali e la legge di Gresham. Atti del III Congresso Internazionale di Numismatica e di Storia Monetaria, Padova, 28-29 ottobre 2005
(Padova: Esedra editrice), 69-101

\section{BERNARDELLI 2006b}

Bernardelli, A., Le monete romane dell'area C7 a Santorso. In: Paoletto, L./De Rossi, M. (eds.), Maggio a Santorso. Arte-tradizionestoria-attualità (Schio: Grafiche Marcolin), 89-91

\section{BERNARDELLI 2014}

Bernardelli, A., L'Impero romano in crisi. Aspetti della tesaurizzazione del bronzo in Italia. In: Un confronto drammatico con il XXI secolo: l'Impero romano del III secolo nella crisi monetaria, Atti del convegno (Biassono, 9 giugno 2012) (Biassono: Edizioni del Museo Civico Carlo Verri), 93-170

\section{BUTTREY 1972}

Buttrey, T.V., A hoard of sestertii from Bordeaux and the problem of bronze circulation in the third century A.D., The American Numismatic Society. Museum Notes 18, 33-58

\section{BUTTREY 1981}

Buttrey, T.V., Monetary circulation at Lyon in the third century A.D., Bulletin de la Société Française de Numismatique 36, 125126

\section{CALLU 1969}

Callu, J.-P., La Politique monétaire des Empereurs Romains de 238 à 311 (Paris: Éditions E. de Boccard)

\section{CALLU 1975}

Callu, J.-P., Approches numismatique de l'histoire du $3^{\text {e }}$ siècle (238-311). In: Temporini, H./Hasse, W. (eds.), Aufstieg und Niedergang der Römischen Welt, II/2, Principat (Berlin/New York: de Gruyter), 595-613

\section{CATTANEO 2016}

Cattaneo, A., La collezione numismatica di Teopisto Strolin donata al Comune di Schio, Archeologia Veneta XXXIX, 223-239

\section{CATTANEO 2017}

Cattaneo, A., "Di poche parole, ma ben coniate come le sue monete". Teopisto Strolin e la sua collezione numismatica (Schio: Comune di Schio)

\section{CORBIER 2005}

Corbier, M., Coinage and taxation: the State's point of view, A.D. 193-337. In: Bowman, A.K./Garnsey, P./Cameron, A. (eds.), The Cambridge Ancient History, XII, The Crisis of Empire (Cambridge: University Press), 327-391 


\section{CRAWFORD 1975}

Crawford, M., Finance, Coinage and Money from the Severans to Constantine. In: Temporini, H./Hasse, W. (eds.), Aufstieg und Niedergang der Römischen Welt, II/2, Principat (Berlin/New York: de Gruyter), 560-593

\section{CRISAFULLI 2008}

Crisafulli, C., Economia monetaria in Italia alla vigilia del IV secolo d.C.: il ruolo dell'antoniniano e dei suoi omologhi gallici alla luce delle fonti numismatiche e storicoletterarie, Phd thesis, Università degli Studi di Padova (http://paduaresearch.cab.unipd. it/473).

\section{CRISAFULLI 2014}

Crisafulli, C., Ritrovamenti monetali. In: Possenti, E. (ed.), San Rocco a Ceneda (Vittorio Veneto). Indagini archeologiche 2003-2006 (Trieste: Editreg), 213-224

FURLANETTO, RIGONI 1987

Furlanetto, P./Rigoni, M., Il territorio vicentino. In: Cavalieri Manasse, G. (ed.), Il Veneto nell'età romana, II. Note di urbanistica e di archeologia del territorio (Verona: Banca Popolare di Verona), 135-156

GAMBA 2012

Gamba, M., Il Monte Summano. Un santuario sulle vie della transumanza. In: Busana, M.S./Basso, P., La lana nella Cisalpina romana. Economia e società. Studi in onore di Stefania Pesavento Mattioli. Atti del Convegno (Padova-Verona, 18-20 maggio 2011) (Padova: Padova University Press), 81-95

GORINI 1976

Gorini, G., Aspetti della circolazione monetale nella Venetia et Histria nel III secolo d.C. In: Frappe et Ateliers Monétaires dans l'Antiquité et Moyen Age. Actes du symposium réuni du 30 janvier au 1er février 1975 dans le Musée National de Belgrade (Belgrade: Musée National), 47-52

\section{GORINI 1987}

Gorini, G., Aspetti monetali: emissione, circolazione e tesaurizzazione. In: Buchi, E. (ed.), Il Veneto nell'età romana, I, Storiografia, organizzazione del territorio, economia $e$ religione (Verona: Banca popolare di Verona), 227-286

GORINI 1993

Gorini, G., Il ripostiglio di bronzi del terzo secolo d.C. da Camin (Padova), Archeologia Veneta XV, 95-100

\section{GORINI 2002}

Gorini, G., Problematiche e metodi di indagine nell'economia monetaria della X Regio. In: Gorini, G. (ed.), Ritrovamenti monetali nel mondo antico: problemi e metodi. Atti del Congresso Internazionale (Padova, 31 marzo-2 aprile 2000) (Padova: Esedra editrice), 177-191

\section{GORINI 2007}

Gorini, G., Il collezionismo di medaglie papali nel XIX e XX secolo. In: Bernardelli, A./Zironda, R. (eds.), Il medagliere dei Musei Civici di Vicenza. Le medaglie papali (Vicenza: Silvana Editoriale), 15-17

\section{GORINI 2010}

Gorini, G., Aspetti del collezionismo numismatico italiano nel '900, Bollettino di Numismatica 54 (luglio-dicembre), La collezione di Vittorio Emanuele III e gli studi di storia monetaria, Atti delle Giornate di Studio per il $1^{\circ}$ Centenario dalla pubblicazione del Corpus Nummorum Italicorum, Roma-Palazzo Massimo alle Terme 22-22 ottobre 2010, 83107

\section{KING 1996}

King, C.E., Roman copies. In: King, C.E./ Wigg, D.G. (eds.), Coin finds and coin use in the Roman World, The thirteenth Oxford Symposium on Coinage and Monetary History (25.-27. 3, 1993), a NATO Advanced Research Workshop (Berlin: Mann), 237-263

\section{LO CASCIO 2005}

Lo Cascio, E., The Age of the Severans. In: Bowman, A.K./Garnsey, P./Cameron, A. (eds.), The Cambridge Ancient History, XII, The Crisis of Empire (Cambridge: University Press), 137-155

\section{PAVONI 2004}

Pavoni, M.G., L'insediamento di Brega. Le Monete. In: Pettenò, E. (ed.), Nelle campagne della Rosa. Dieci anni di ricerche archeologiche a Rosà (Bassano del Grappa: Editrice Artistica Bassano), 116-123

RIC

The Roman Imperial Coinage, I-X, 1923-2007 (London)

RMRVe, I/1

Marcer, J., Ritrovamenti monetali di età Romana nel Veneto, I/1, Provincia di Belluno: Belluno, 2006 (Padova: Esedra editrice)

$R M R V e, \mathrm{II} / 1$

Bernardelli, A./Callegher, B./Gorini, G./ Saccocci, A., Ritrovamenti monetali di 
età Romana nel Veneto, II/1, Provincia di Treviso: Treviso, 1995 (Padova: Editoriale programma)

RMRVe, II/2

Callegher, B., Ritrovamenti monetali di età Romana nel Veneto, II/2, Provincia di Treviso: Oderzo, 1992 (Padova: Editoriale programma)

RMRVe, IV/1

Bernardelli, A., Ritrovamenti monetali di età Romana nel Veneto, IV/1, Provincia di Vicenza: Vicenza, 1995 (Padova: Editoriale programma)

RMRVe, IV/2

Bernardelli, A., Ritrovamenti monetali di età Romana nel Veneto, IV/2, Provincia di Vicenza: Bassano, 1997 (Padova: Esedra editrice)

RMRVe, VI/1

Asolati, M./Crisafulli, C., Ritrovamenti monetali di età Romana nel Veneto, VI/1, Provincia di Venezia: Altino I, 1999 (Padova: Esedra editrice)

RMRVe, $\mathrm{VI} / 2$

Asolati, M./Crisafulli, C., Ritrovamenti monetali di età Romana nel Veneto, VI/2, Provincia di Venezia: Altino II, 1994 (Padova: Editoriale programma)

RMRVe, $\mathrm{VI} / 3$

Asolati, M./Crisafulli, C., Ritrovamenti monetali di età Romana nel Veneto, VI/3, Provincia di Venezia: Chioggia, 1993 (Padova: Editoriale programma)

SACCOCCI 1988

Saccocci, A., Il ripostiglio di sesterzi da Mussolente. In: Museo di Bassano. Scuola e Museo. Itinerari 1979-1985 (Bassano: Cassa di risparmio di Verona Vicenza e Belluno), 113-114

SORDA 1981

Sorda, S., Due tesoretti di fine II secolo d.C. dalla VI Regio, Annali dell'Istituto Italiano di Numismatica 27/28, 79-113

TAGLIAFERRO 1935

Tagliaferro, G., Monete e Medaglie, Bollettino Parrocchiale di Schio III/7 (1 luglio 1935), 9-10 
Plates
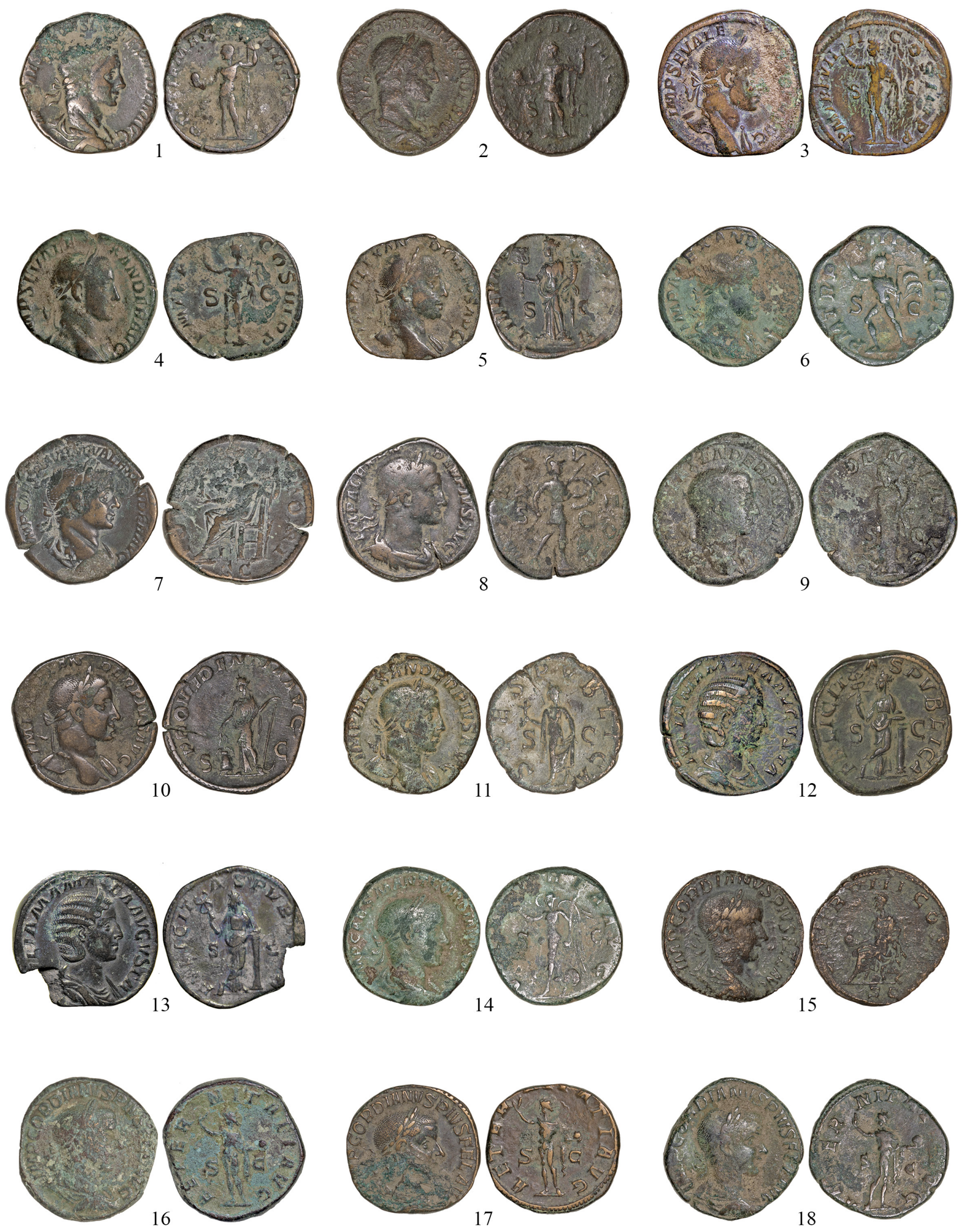



25
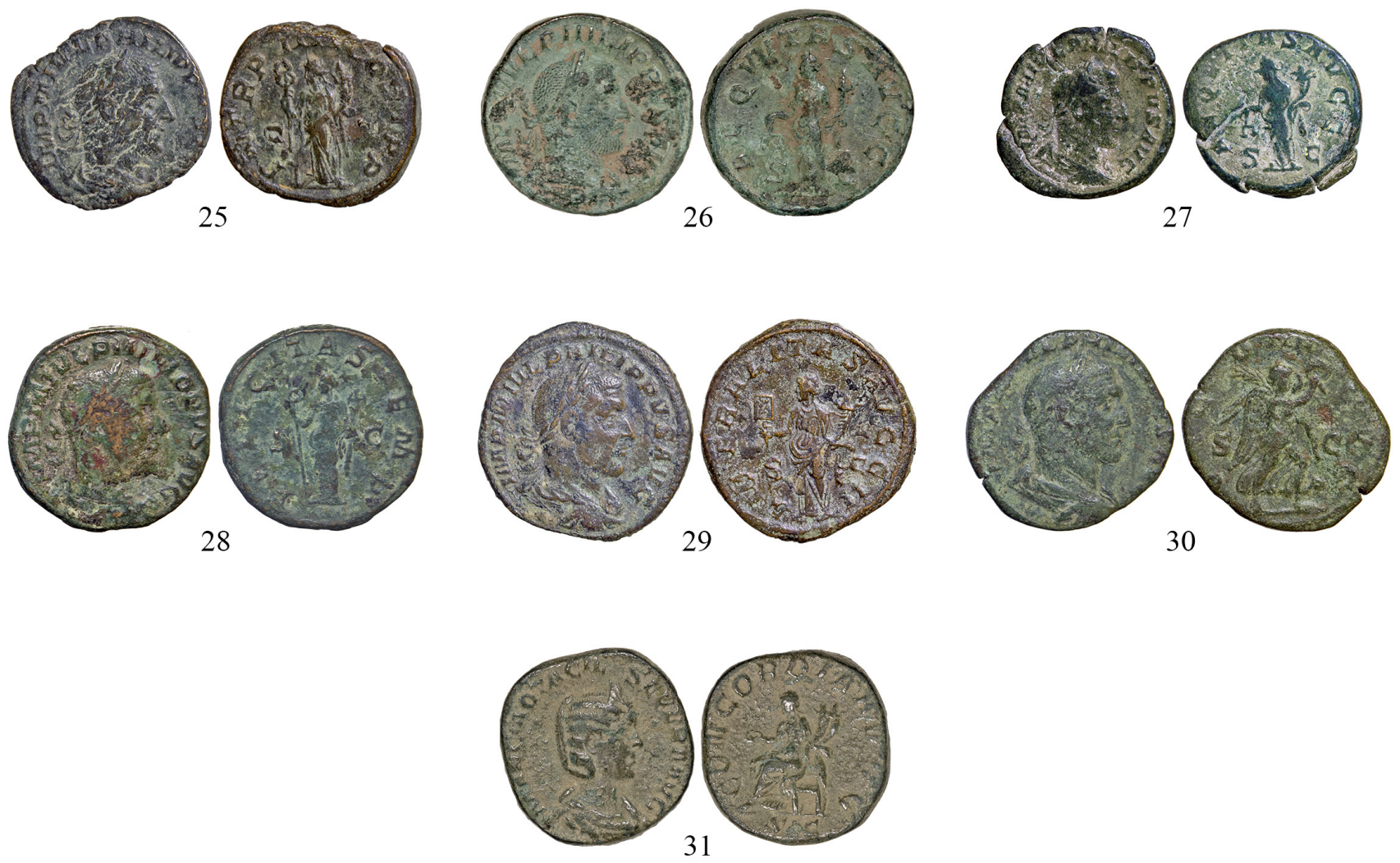
